\title{
SPECIFICS AND DIAGNOSTIC PROCEDURE IN REFLUX-RELATED DYSPHONIA
}

D0I: 10.36740/WLek202004137

\author{
Klaudia Sowa' , Anna Łobaczuk-Sitnik', Bartosz Piszczatowski², Emilia Duchnowska', Bożena Kosztyła-Hojna', \\ Klaudiusz Nadolny ${ }^{3,4}$, Jerzy Robert Ładny ${ }^{3}$, Maciej Zdrojkowski ${ }^{1}$ \\ 'DEPARTMENT OF CLINICAL PHONOAUDIOLOGY AND SPEECH THERAPY, MEDICAL UNIVERSITY OF BIALYSTOK, BIALYSTOK, POLAND \\ 2DEPARTMENT OF OTOLARYNGOLOGY, MEDICAL UNIVERSITY OF BIALYSTOK, BIALYSTOK, POLAND \\ ${ }^{3}$ DEPARTMENT OF EMERGENCY MEDICINE, MEDICAL UNIVERSITY OF BIALYSTOK, BIALYSTOK, POLAND \\ ${ }^{4}$ DEPARTMENT OF EMERGENCY MEDICAL SERVICE, STRATEGIC PLANNING UNIVERSITY OF DABROWA GORNICZA, DABROWA GORNICZA, POLAND
}

\begin{abstract}
Voice is a work tool for many professional groups. Currently, cases of dysphonia of multiple origin consist a growing issue. Voice disorders may result from disturbed voice production process, congenital defects, post-traumatic conditions, chronic diseases or hormonal disorders. Chronic diseases causing voice disorders include laryngopharyngeal reflux disease and esophageal reflux disease.

The chronic character of reflux causes the formation of numerous morphological changes of the larynx, including: hyperemia of the mucosa limited to arytenoid and intraarytenoid area, edema of the vocal folds, edema of the larynx mucosa. These changes contribute to voice disorders. Among the pathological changes of voice organ etiologically associated with reflux, the following disease units may be distinguished: reflux laryngitis, subglottic edema, contact ulceration, larynx granuloma, larynx and pharynx cancer. Many of disorders in the upper respiratory tract are etiologically related to reflux, e.g. dysphonia, grunting, coughing and dyspnoea.
\end{abstract}

KEY WORDS: dysphonia, gastroesophageal reflux disease

\section{INTRODUCTION}

Voice is a work tool for many professional groups. The proper professional functioning of teachers, radio journalists, actors and opera singers depends on the condition of their voice organ. Three organ structures are involved in the voice creation process. The first is larynx, which is a sound acoustic energy generator. The second group includes: lungs, bronchi, trachea; which are an air reservoir necessary for articulation and phonation. The generated air stream creates vibrations of vocal folds. Laryngeal tone is produced in the glottis, which has its characteristic timbre in upper resonators (oral cavity, nasal cavity, throat) and lower resonators. The last group includes the structures necessary to create speech sounds, i.e. the articulatory organ.

Currently, cases of dysphonia of multiple origin consist a growing issue. Voice disorders may result from disturbed voice production process, congenital defects, post-traumatic conditions, chronic diseases or hormonal disorders. Chronic diseases causing voice disorders include laryngopharyngeal reflux disease and esophageal reflux disease [1-4].

The definition of GERD (Gastro-esophageal reflux disease) adopted in 2006 at the Gastrological Congress in Montereal states that it is a disease in which the reflux of acid content into the esophagus causes symptoms or complications that severely affect patient's functioning and comfort. Patients whose esophagus $\mathrm{pH}$ decreases below 4 and stays at that level for more than one hour, reflux episodes occur more than 50 times a day, regardless of the time of day, and their duration is long - are diagnosed with pathological reflux. The clinical manifestations of GERD are numerous and diverse. The severity depends on the position of patient's body and diet. The ailments intensify after large, greasy meal, in supine position or while leaning. Patients suffer from heartburn, vomiting, belching, nausea, regurgitation, sour taste in the mouth, and epigastric pain. In addition to the large range of gastrological symptoms, patients also report ENT symptoms such as dysphagia, hoarseness, and the globus pharyngeus [5-10].

Changes in the voice organ etiologically related to reflux include: reflux laryngitis, subglottic edema, contact ulceration, larynx granuloma as well as larynx cancer and lower throat cancer. In reflux laryngitis, reflux into the esophagus causes acute or chronic changes as well as damage to the esophageal mucosa. The clinical features of reflux disease are edema in the larynx - arytenoid edema, intra-arytenoid area, and edema of the vocal fold. The main symptoms of reflux laryngitis include chronic voice disturbances, manifesting in morning hoarseness and voice fatigue in the evening. The need for clearing the throat of thick secretions is frequently observed [18-20]. 
Subglottic edema is observed in the area between the anterior commissure and the posterior larynx region. Scientific research conducted by Hickson [21] showed that the probability of occurrence of reflux in patients with subglottic edema is over $90 \%$.

Larynx granulomas are benign but often recurrent lesions of the arytenoid vocal processes region. Closing vocal processes cause damage to the mucoperichondrium, the food content of the larynx and esophagus, which prevents the wound from healing and leads to inflammation and subsequent ulceration. Gastroesophageal reflux episodes prevent the recovery process in the larynx, granulation tissue covers ulceration of the squamous epithelium as a result of which granulomas develop [22-24].

The main etiological factors of laryngeal cancer are smoking and alcohol consumption. Pathological reflux causes chronic laryngitis due to regurgitation of acid content to the throat and larynx. Chronic inflammatory process may act carcinogenously. It should also be noted that alcohol deteriorates esophageal mobility, cigarettes stimulate gastric acid secretion, and both factors delay gastric emptying, reduce the tension of the lower esophageal sphincter, thereby enhance the symptoms of reflux disease $[23,24]$.

Disorders from the upper respiratory tract etiologically associated with reflux include: dysphonia, grunting, coughing, dyspnea, globus pharyngeus, and heartburn [24-26].

Patients struggling with GERD have numerous morphological changes in the larynx. These changes mainly include mucosa and increased external and internal laryngeal muscle tone. Mucosal changes and the presence of excessive mucus in the supraglottic region cause voice disorders. Prolonged laryngeal hyperfunction contributes to secondary organic changes in the voice organ. Overloading and disturbed voice production process intensify the symptoms. Edema, retention of thick respiratory secretions significantly increases the mass of vocal folds, which consequently reduces voice scale. Variation in voice resonators location, among others, laryngeal ventricles, contribute to changes in tone quality [25-27].

Among the symptoms of phoniatric nature, patients complain of the need for frequent clearing of the throat and a feeling of obstruction in the throat. The need for clearing throat is caused by increased salivation, which is the result of acid content regurgitation to the esophagus. The chemical composition of saliva contains bicarbonates, which have gastric acid neutralizing properties. In extreme cases, when the number of reflux episodes is very high, patients may suffer from excessive salivation. Regurgitation of the acid content into the esophagus is accompanied by reflex tension of the throat and larynx muscles, which causes a feeling of obstruction in the throat, i.e. the globus pharyngeus $[23,25,26]$.

Irwin et al. [25], among 3 main causes of chronic cough, next to asthma and sinusitis disease, mention reflux. Reflux-dependent cough is based on two mechanisms: microaspiration and esophageal-tracheal-bronchial cough reflex. Cough not associated with reflux may disturb the pressure gradient differences between the abdominal cavity and the thorax. The consequence of these disorders is a decrease in the functional pressure of the lower esophageal sphincter, which will lead to reflux incidents $[25,27,28]$.

Reduction of respiratory surface of the glottis, caused by regurgitation of acid content into the esophagus, may contribute to the formation of granulomas, edema of the posterior commissure and vocal folds, immobilization of cricoarytenoid joint or occurrence of paroxysmal laryngeal spasm manifesting as dyspnea [27, 28].

In the initial stage of the diagnostic procedure of reflux disease, in addition to the physical examination and medical history, a standardized scale of reflux symptoms - Reflux Symptoms Index (RSI) is used. The patient answers 9 questions about reflux-related ailments, indicating the severity of the symptoms on a scale of 0 to 5 , where 0 means that the problem has never occurred and 5 means that it consists a serious problem. Gastrological diagnosis of reflux includes such tests as 24 -hour $\mathrm{pH}$-meter, endoscopy, esophageal manometry $[9,11-13]$.

Patients with gastroesophageal reflux disease complaining of voice disorders should receive phoniatric care. In the diagnosis of voice disorders resulting from the morphological changes of the larynx caused by reflux, objective tests are used, such as videolarygostroboscopy (VLLS) and subjective tests: voice perceptual assessment - GRBAS scale, as well as a self-questionnaire determining the voice disability - Voice Handicap Index (VHI) [14-16].

\section{REVIEW AND DISSCUSION}

\section{GRBAS SCALE}

Perceptual assessment, i.e. voice auscultation and voice production assessment, are performed at the first visit. The GRBAS scale is an international scale proposed by the Japanese Society of Speech Therapists and Phoniatricians, describing voice disorders within the following five parameters: $G$ (grade) - grade of hoarseness, $R$ (roughness) - roughness of voice, $B$ (breathiness) - breathiness of voice, A (asthenicity) - asthenicity of voice, S (strain) - voice strain. Each parameter is assessed in degrees of intensity from 0 to 3 , where 0 is a physiological voice and 3 is a high severity of symptoms $[14,15]$.

\section{VOICE HANDICAP INDEX (VHI)}

Voice Handicap Index (VHI) or voice disability index is a voice quality self-assessment questionnaire containing 30 questions divided into 3 subgroups (emotional, physical and functional conditions). The patient completes the questionnaire by answering the questions in order to determine the quality of voice disorders in his subjective self-assessment. Each question has a 5-point scale: 0 never; 1 - almost never; 2 - sometimes; 3 - almost always; 
4 - always. After completing the survey by the patient, the examiner counts the number of points from each category separately and summarizes the number of points from all categories. The patient may receive from 0 to 120 points. Score from 0 to 30 points indicates a slight voice disability, 31-60 - average voice disability, and above 30 points - severe voice disability [14-16].

\section{VIDEOLARYNGOSTROBOSCOPY (VLLS)}

Videolaryngostroboscopy (VLLS) is a modern examination used in the diagnosis of voice disorders. The phoniatrician using a rigid endoscope with a camera and visual track, observes vocal folds during phonation. A thorough analysis of the anatomical structure and functioning of vocal folds is possible with the application of stroboscopic light. The course of the examination is recorded, which allows the diagnostician to perform a thorough analysis of the course of vocal fold vibrations $[14,16,17]$.

\section{CONCLUSIONS}

1. Ailments of the upper respiratory tract etiologically related to reflux disease include dysphonia, grunting, coughing, shortness of breath, globus pharyngeus, heartburn and regurgitation.

2. Gastroesophageal reflux disease causes morphological changes in the larynx such as hyperemia and edema of the mucosa, edema of vocal folds, hypertrophy of the mucosa of posterior commissure, which contribute to the development of voice disorders.

3. Specialistic phoniatric diagnostics of patients with gastroesophageal reflux disease allows to identify voice disorders connected with morphological changes of the larynx resulting from a chronic disease process.

4. Complex phoniatric care for patients suffering from gastroesophageal reflux disease allows to reduce complaints from the voice organ.

\section{REFERECES}

1. Zdziarski K. Emisja głosu. Szczecińska Szkoła Wyższa Collegium Balticum. Szczecin. 2011; p. $8-20$.

2. Stankiewicz C, Behrbohm H, Kaschke 0 et al. Choroby ucha, nosa i gardła z chirurgią głowy. (Gołąbek W ed.) Poznań: Elservier Urban \& Partner, 2011; pp. 297-306.

3. Obrębowski A, Pruszewicz A, Sekula A et al. Mechanizm powstawania głosu. In: Obrębowski A (ed.) Narząd głosu i jego znaczenie w komunikacji społecznej. Poznań: Wydawnictwo Naukowe Uniwersytetu w Poznaniu, 2008; pp. 28-30.

4. Kazanecka E, Szkiełkowska A, Sakrżyński H. Kryteria oceny czynności nadgłośniowej części krtani i gardła w czasie tworzenia głosu. Nowa Audiofonolog. 2013;31-35.

5. Skrzypczak W, Kowalska B. Zmiany w krtani w przebiegu choroby refluksowej. Ann Acad Med Gedan. 2011;115-123.

6. Krogulska A, Wąsowska-Królikowska K. Refluks żołądkowoprzełykowy a refluks krtaniowo-gardłowy - znaczenie w laryngologii. Otorynolaryngol Pol. 2009;8(2):45-52.
7. Korzonek M, Dziergas A, Kuczyńska M. Choroba refluksowa przełyku (GERD) - problem wciążaktualny. Forum Med Rodz. 2014;8(5):201-210.

8. Samborski P, Grzymisławski M. Laryngologiczna manifestacja choroby refluksowej przełyku u chorych z otyłością - nowości w diagnostyce i leczeniu. Forum Zab Metabol. 2015;6(1): 31-36

9. Fass R, Gerson LB. A systematic review of the definitions, prevalence, and response to treatment of nocturnal gastroesophageal reflux disease. Clin Gastroenterol Hepatol. 2009;7:372-378.

10. Barry DW, Vaezi MF. Laryngopharyngeal reflux: more questions than answers. Cleve Clin J Med. 2010;77(5):327-34.

11. Dymek A, Dymek L. Refluks krtaniowo-gardłowy. Warszawa: Wydawnictwo lekarskie PZWL, 2013.

12. Banks M. Choroba refluksowa przełyku: najnowsze badania i postępowanie. Med Dypl. 2010;19(10):39 - 48.

13. Prakash C, Clouse RE. Value of extended recording time with wireless $\mathrm{pH}$ monitoring in evaluating gastroesophageal reflux disease. Clin Gastroenterol Hepatol. 2009;372-378.

14. Behlau M, Alves Dos Santos L de M, Oliviera G. Cross cultural adaptation and validation of the Voice Handicap Index into Brasilian Portuguese. J Voice. 2011;25(3):354-9.

15. Morzaria S, Damrose EJ. A comparison of the VHI, VHI-10, and V-RQOL for measuring the effect of botox theraphy in adductor spasmodic dysphonia. J Voice. 2012; 26(3):378 - 80.

16. Kopczyński B, Strumiłło P, Niebudek- Bogusz E. Ocena funkcji fonacyjnej krtani z zastosowaniem komputerowej analizy obrazów laryngowideostroboskopowych- badania pilotażowe. Otolaryngol Pol. 2014; 13(3):139-146.

17. Pomirska E, Szkiełkowska A, Domeracka-Kołodziej A et al. Subiektywna ocena jakości głosu w refluksowym zapaleniu krtni - doniesienia wstępne. Nowa Audiofonologia. 2017;6(1):52-60.

18. Trojanowska E, Bieńkiewicz B, Kowalski M. Choroba refluksowa przełyku a choroby układu oddechowego. Alergia Astma Immunologia. 2015;20(1):40-45.

19. Domeracka-Kołodziej A. Refluks krtaniowo-gardłowy w praktyce foniatrycznej. Pol Otorhino Rev. 2013;2:159-164.

20. Wallner G, Solecki M, Wróblewski T et al. Choroba refluksowa przełyku - zalecenia dla praktyki klinicznej. Wideochir Inne Tech Maloinwazyjne. 2009;4(Supl1):S53-S61.

21. Hickson C, Simpson CB, Falcon R. Laryngeal pseudosulcus as a predictor of laryngopharyngeal reflux. Laryngoscope. 2001;111:1742-1745.

22. Domeracka-Kołodziej A, Grabczak E, Dąbrowska M et al. Porównanie jakości głosu osób z refluksowymi zmianami w krtani i gardle dolnym przed leczeniem i po nim. Otolaryngol Pol. 2015;69(1):47 - 56.

23. Scech M. Wskaźnikniepełnosprawności głosowej-efektywnośći korelacja pomiędzy cechami fizycznymi, funkcjonalnymi oraz emocjonalnymi a zaburzeniami głosu. Pomeranian J Life Sci. 2016;62(1):9-15.

24. Domeracka-Kołodziej A, Grabczak EM, Dąbrowska M et al. Skala Warszawska A-E oceny endoskopowych zmian w krtani związanych z refluksem gardłowo-krtaniowym. Korelacja ze skalą patologii refluksowej (RFS). Otolaryngol Pol. 2014;68:189-195.

25. Irwin RS, Madison JM. Anatomic diagnostic protocol in evaluating chronic cough with specific reference to gastroesophageal reflux disease. Am J Med. 2000;108:126-130.

26. Domeracka-Kołodziej A, Grabczak EM, Dąbrowska M. Comparison of voice quality in patients with GERD-related larynx and layngopharynx disorders before and after therapy. Otolaryngol Pol. 2015;69(1):47-56.

27. Barry DW, Vaezi MF. Laryngopharyngeal reflux: More questions than answers. Cleve Clin J Med. 2010;77(5):327-34. 


\section{ORCID and contributionship}

Klaudia Sowa - 0000-0002-9727-8644 B,D

Anna Łobaczuk-Sitnik - 0000-0002-9765-7986 A,D,E,F

Bartosz Piszczatowski - 0000-0003-4471-0664 ${ }^{\text {B,E }}$

Emilia Duchnowska - 0000-0002-9213-1416 D,E,F;

Klaudiusz Nadolny - 0000-0003-0355-241X ${ }^{E, F}$

Bożena Kosztyła-Hojna - 0000-0001-5867-4890 A,E,F

Maciej Zdrojkowski-0000-0002-5767-9558 ${ }^{D}$

Jerzy Robert Ładny - 0000-0003-4167-1962 E,F

\section{Conflict of interest}

Authors declare no conflict of interest.

\section{CORRESPONDING AUTHOR}

Emilia Duchnowska

Department of Clinical Phonoaudiology and Speech Therapy,

Medical University of Bialystok

Szpitalna str 37, 15-295 Białystok, Poland

tel.: +48603330294

e-mail: emilia.duchnowska@umb.edu.pl

Received: 08.01.2020

Accepted: 18.03 .2020

A - Work concept and design, B - Data collection and analysis, C - Responsibility for statistical analysis,

D-Writing the article, $\mathbf{E}$ - Critical review, $\mathbf{F}$ - Final approval of the article 